\title{
The receptor for Granulocyte-colony stimulating factor (G-CSF) is expressed in radial glia during development of the nervous system Friederike Kirsch ${ }^{\dagger}$, Carola Krüger ${ }^{\dagger}$ and Armin Schneider*
}

\author{
Address: SYGNIS Bioscience, Im Neuenheimer Feld 515, 69120 Heidelberg, Germany \\ Email: Friederike Kirsch - Kirsch@sygnis.de; Carola Krüger - Krueger@sygnis.de; Armin Schneider* - Schneider@sygnis.de \\ * Corresponding author †Equal contributors
}

Published: 27 March 2008

BMC Developmental Biology 2008, 8:32 doi:10.1/86/|47|-2/3X-8-32
Received: I August 2007

Accepted: 27 March 2008

This article is available from: http://www.biomedcentral.com/I47I-2/3X/8/32

(C) 2008 Kirsch et al; licensee BioMed Central Ltd.

This is an Open Access article distributed under the terms of the Creative Commons Attribution License (http://creativecommons.org/licenses/by/2.0), which permits unrestricted use, distribution, and reproduction in any medium, provided the original work is properly cited.

\begin{abstract}
Background: Granulocyte colony-stimulating (G-CSF) factor is a well-known hematopoietic growth factor stimulating the proliferation and differentiation of myeloid progenitors. Recently, we uncovered that G-CSF acts also as a neuronal growth factor in the brain, which promotes adult neural precursor differentiation and enhances regeneration of the brain after insults. In adults, the receptor for G-CSF is predominantly expressed in neurons in many brain areas. We also described expression in neurogenic regions of the adult brain, such as the subventricular zone and the subgranular layer of the dentate gyrus. In addition, we found close co-localization of the G-CSF receptor and its ligand G-CSF. Here we have conducted a systematic expression analysis of G-CSF receptor and its ligand in the developing embryo.
\end{abstract}

Results: Outside the central nervous system (CNS) we found G-CSF receptor expression in blood vessels, muscles and their respective precursors and neurons. The expression of the G-CSF receptor in the developing CNS was most prominent in radial glia cells.

Conclusion: Our data imply that in addition to the function of G-CSF and its receptor in adult neurogenesis, this system also has a role in embryonic neurogenesis and nervous system development.

\section{Background}

Granulocyte colony-stimulating (G-CSF) factor is a secreted glycoprotein of $20 \mathrm{kDa}$ traditionally known as a hematopoietic growth factor stimulating the proliferation and differentiation of myeloid progenitors [1,2]. It is clinically used for the treatment of chemotherapy-associated neutropenia and for the mobilization of stem cells for bone-marrow transplantations. In addition to this hematopoietic function, we recently described important functions in the central nervous system (CNS), including antiapoptotic properties on mature neurons, as well as a neurogenic function in adult neural stem cells [3]. G-CSF and its receptor are widely expressed in the adult CNS and induced upon cerebral ischemia. Besides reducing infarct volumes in stroke, G-CSF enhances long-term recovery after insults to the brain, which is linked to an increase in neurogenesis [3-5]. Taken together, these data underline the clinical relevance of G-CSF as a potential new drug for stroke and other neurodegenerative disorders (for review see [6]).

G-CSF and its receptor show a broad, mainly neuronal, colocalized expression throughout the murine brain [3]. Beside the expression in pyramidal neurons in the cortex (mainly layers II/III and V), the Purkinje cell layer of the cerebellum, the hippocampus (hilus and CA3 field), the 
entorhinal cortex and the olfactory bulb, G-CSF is also expressed in neurogenic regions in the adult brain: in the subgranular zone of the dentate gyrus and the subventricular zone. To see whether the expression in the nervous system of the adult organism had any correlation to embryonic expression of the receptor, we performed an expression pattern study of the G-CSF receptor during CNS development of the mouse embryo.

\section{Results \\ G-CSF receptor expression outside the CNS throughout development of the rat embryo}

In order to analyze the G-CSF receptor expression in the murine embryonic development, we performed immunohistochemical stainings. Figure 1 gives examples of G-CSF receptor expression outside the developing CNS from E11-E19. G-CSF receptor expression can be found in vessels of the cardiac ventricle (Figure 1A; E11), of the intestine (Figure 1B, O; E12 and E19), of glomeruli in the kidney (Figure 1C, M, N; E12 and E19) and in the wall of blood vessels (Figure 1F; E16). Moreover, the G-CSF receptor is expressed in neurons of the upper cervical dorsal root ganglia (Figure 1G, H; E16), in nerve fibers and muscles of the tongue (Figure 1E, I, J; E12 and E16) and in the developing retina (Figure 1L; E16). Receptor expression was also detected in muscle precursors (somite, Figure 1D; E12) and muscles (e.g. the external ocular muscles in the eye (Figure 1K; E16). In addition, its expression can be observed in the lens fibers of the eye (Figure 1L; E16).

\section{Identification of $m R N A$ expression of the G-CSF receptor and G-CSF in the developing CNS}

Next we analyzed the G-CSF receptor expression in the developing CNS. We detected expression of the G-CSF receptor and G-CSF during murine embryonic CNS development by reverse transcriptase PCR (RT-PCR). In heads or brains of embryo development stages E11 - E18 and postnatal day 2 (P2, Figure 2) PCR yielded the expected product sizes (235 bp for G-CSF receptor and $360 \mathrm{bp}$ for G-CSF). G-CSF and its receptor are detected as early as E11, and are expressed continuously throughout P2.

\section{Immunohistochemical localization of the G-CSF receptor in the developing CNS}

By immunohistochemistry, the RNA signal of the G-CSF receptor at $\mathrm{E} 11$ corresponds to protein expression in the telencephalic vesicle of the E11 embryo (Figure 3A). Later in development we found G-CSF receptor expression in other CNS regions, for example in the developing spinal cord (Figure 3B, D, E; E12 and E16), in the hindbrain (Figure 3C, G; E16, E19), in the olfactory bulb (Figure 3H; E19), in the diencephalon (Figure 3I; E21) and in the retina (Figure 1L, E16). Cells with G-CSF receptor expression commonly displayed long and fine processes, which pass through the neuroepithelial layer and terminate in small end feets at the pial surface (e.g in Figure 3A). This morphology matches exactly that described for radial glia cells by Ramón y Cajal [7]. During postnatal development the radial glia scaffold decreases and the G-CSF receptor is expressed in developing neurons (Additional file 1).

In addition, we found G-CSF receptor expression in structures of the peripheral nervous system such as the dorsal root ganglion and axon roots originating from the ventral spinal cord (Figure 3B; E12).

\section{G-CSF receptor and Nestin co-localize in the EI 6 rat embryo}

To further prove that the structures which express the GCSF receptor in the developing nervous system are radial glia cells, we performed co-immunofluorescence labeling with the stem cell marker Nestin, which labels radial glia cells at these embryonic stages (e.g. [8]). Figure 4 shows a complete overlap of G-CSF receptor and Nestin signals in cortex (Figure 4A-C), diencephalon (Figure 4D-F) and spinal cord (Figure 4G-I) tissue.

\section{Discussion}

The embryonic expression pattern of the G-CSF receptor can be divided into three main categories. The first category with prominent G-CSF receptor expression consists of blood vessels (e.g. the cardiac ventricles, in the intestine, in the glomerular system of the kidney and in blood vessels in the CNS (Figure 1A-C, 1F, 1M-O). Expression in endothelial cells in the embryo is expected as the G-CSF receptor is expressed in adult blood vessels, and G-CSF has considerable effects on endothelial cell functions [911]. Expression in blood vessels in the brain likely forms the basis for blood-brain barrier penetration of G-CSF $[3,12]$, and for effects on G-CSF-induced vascular remodeling after stroke $[13,14]$ or myocardial infarction [15].

The second category with G-CSF receptor expression is formed by muscles and their progenitors (e.g. somites and ocular muscle, Figure 1D, K).

Neurons represent the third category, where high abundance of G-CSF receptor expression was observed in the rat embryo (e. g. in the tongue, the upper cervical dorsal root ganglia, Figure 1E, 1G-J). Broad neuronal expression of G-CSF receptor and its ligand have been detected in the adult CNS $[3,16]$. Using RT-PCR, we detected embryonic expression of G-CSF receptor and G-CSF from E11 up to postnatal day 2 in the brain, respectively head of mice, consistent with the immunohistochemical detection. The embryonic expression pattern of the G-CSF receptor in the CNS is characterized by staining of elongated radial processes crossing through the developing neuroepithelium (Figure 3) and terminating in conical endfeet at the the pial surface (Figure 3A, G, I). We identified these cells as 

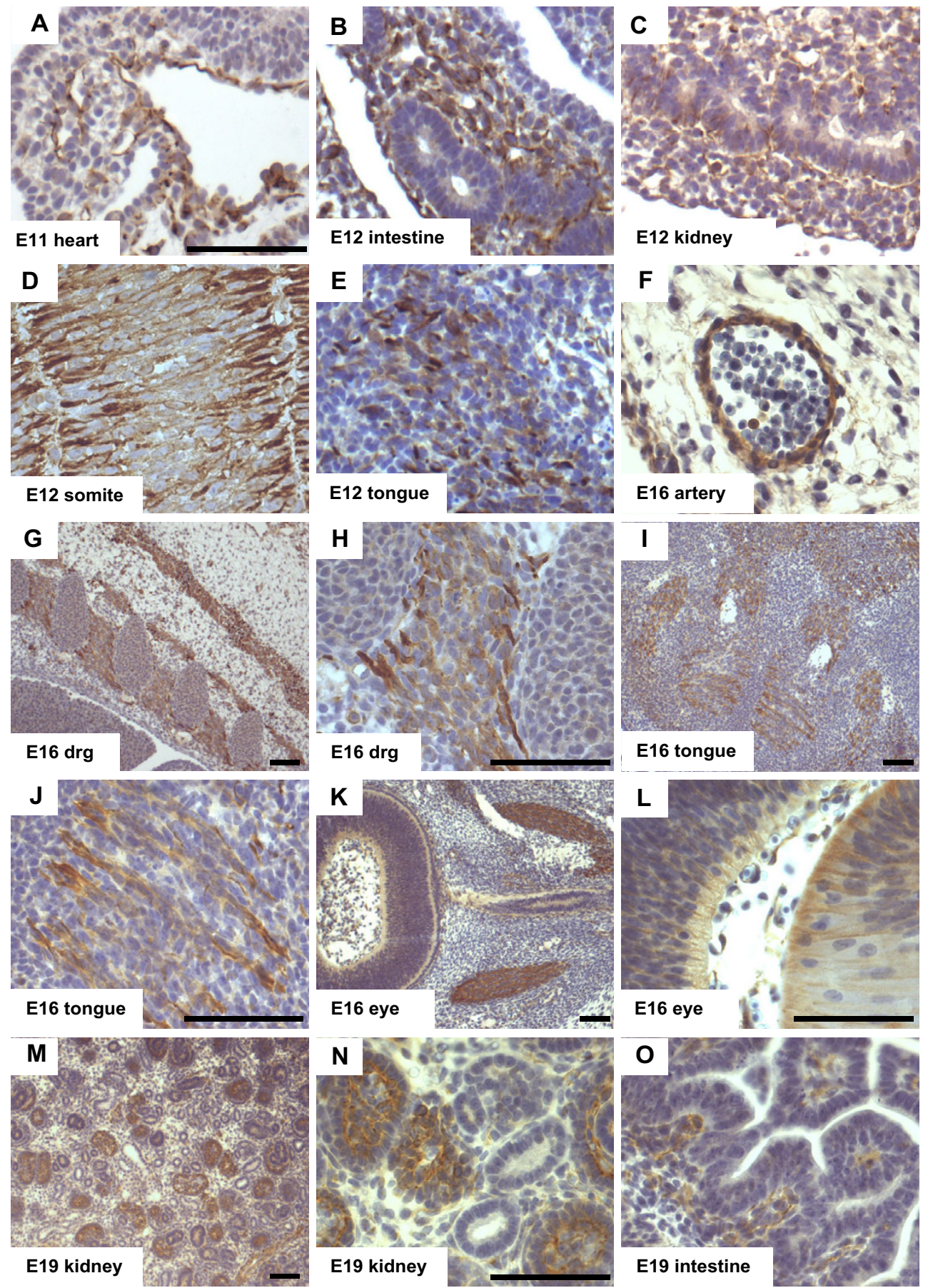

\section{Figure I}

The G-CSF receptor is expressed in structures outside the brain throughout development of the rat embryo. The figure gives an overview of the G-CSF receptor expression pattern in the rat embryo. A EII heart, B EI2 intestine, C EI2 kidney, D EI2 somite, E EI2 tongue, F EI6 cerebral artery, G, H EI6 cervical dorsal root ganglia, I, J EI6 tongue, K, L EI6 eye, M, N EI9 kidney, O EI9 intestine, (Immunohistochemical staining of $10 \mu \mathrm{m}$ paraffin sections, scale bar $50 \mu \mathrm{m}$, drg: dorsal root ganglia, E: embryonic day) 

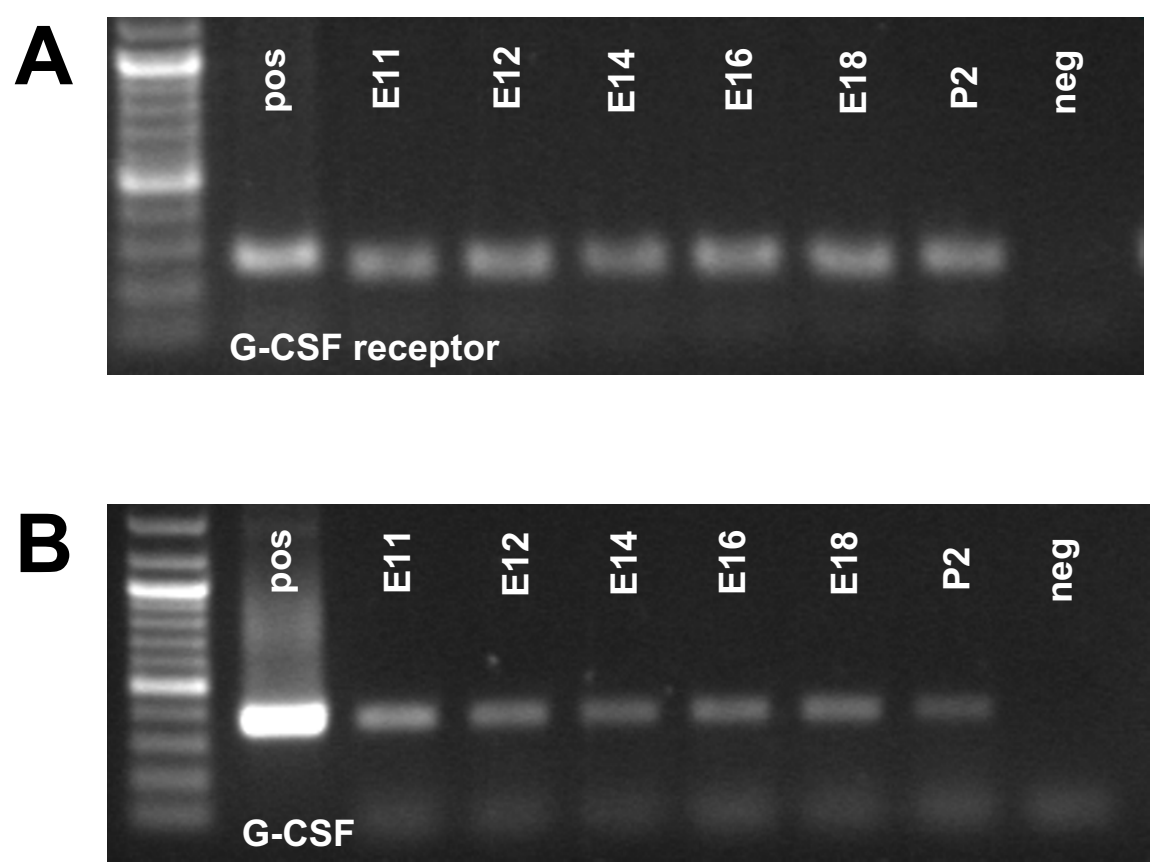

Figure 2

Expression of G-CSF and its receptor on the RNA level. G-CSF receptor (A) and its ligand G-CSF (B) are present throughout murine embryonic development, which is demonstrated by RT-PCR. RT-PCR products of the following stages were loaded on the gels: EI I, EI2, EI4, EI6, EI 8 and P2. As positive controls for G-CSF and G-CSF receptor sequence-verified cDNA clones were used. The negative control consisted of water. RNA was prepared out of EII and EI2 whole embryonic mouse heads, for the other stages mouse brain was taken. Primers are located in the 3' part of the open reading frames with product lengths of 235 bp for G-CSF receptor and 360 bp for G-CSF. (Pos., positive PCR control (G-CSF or G-CSF receptor, respectively; neg., negative control)

radial glia because of their unique morphology and coexpression of the intermediate filament protein Nestin (initially described as monoclonal antibody Rat-401) $[17,18]$. Because of their long processes, radial glia cells were originally interpreted as a transient scaffold upon which nascent neurons should migrate to their definitive positions $[19,20]$. In recent years, the view of radial glia cells as pure supportive cells has changed dramatically. They are now regarded as multifunctional cells involved in many aspects of brain and spinal cord development. One important feature of radial glia might be the involvement in CNS regionalization. In hindbrain development for example, it has been shown that rhombomere boundaries are formed by radial glia cells in order to limit neuronal migration [21]. Most intriguing however, is the recent perception that radial glia cells are the neuronal progenitors that generate neurons in the cerebral cortex $[22,23]$. The remaining adult neural stem cells found for example in the subventricular zone of the lateral ventricle in the rodent forebrain are derived from the embryonic radial glial population [24-26]. This strong relationship between radial glia and adult stem cells is further highlighted by the fact that adult NSCs can redifferentiate to radial glia [27]. The finding that the G-CSF receptor is found on radial glial cells is therefore fully concordant with our data on the later expression of the receptor on adult neural stem cells $[3,28]$.

\section{Conclusion}

Implications from our finding are threefold: First, it adds a further dimension to the presence of the GCSF system in the nervous system (i.e. embryonic expression and a likely significance early in development of the nervous system). Second, it underlines the link between radial glial cells and adult neural stem cells where G-CSF has functional relevance. Third, our data provide a new and highly specific marker (G-CSFR) for radial glial cells throughout cortical neurogenesis.

\section{Methods}

\section{Immunohistochemistry}

Wistar rat embryos were fixed in 4\% paraformaldehyde and embedded in paraffin. $10 \mu \mathrm{m}$ paraffin sections were deparaffinized and microwaved in citrate buffer. For GCSF receptor staining sections were blocked in $1 \% \mathrm{H}_{2} \mathrm{O}_{2}$ in TBS for 30 minutes at room temperature. After washing, 

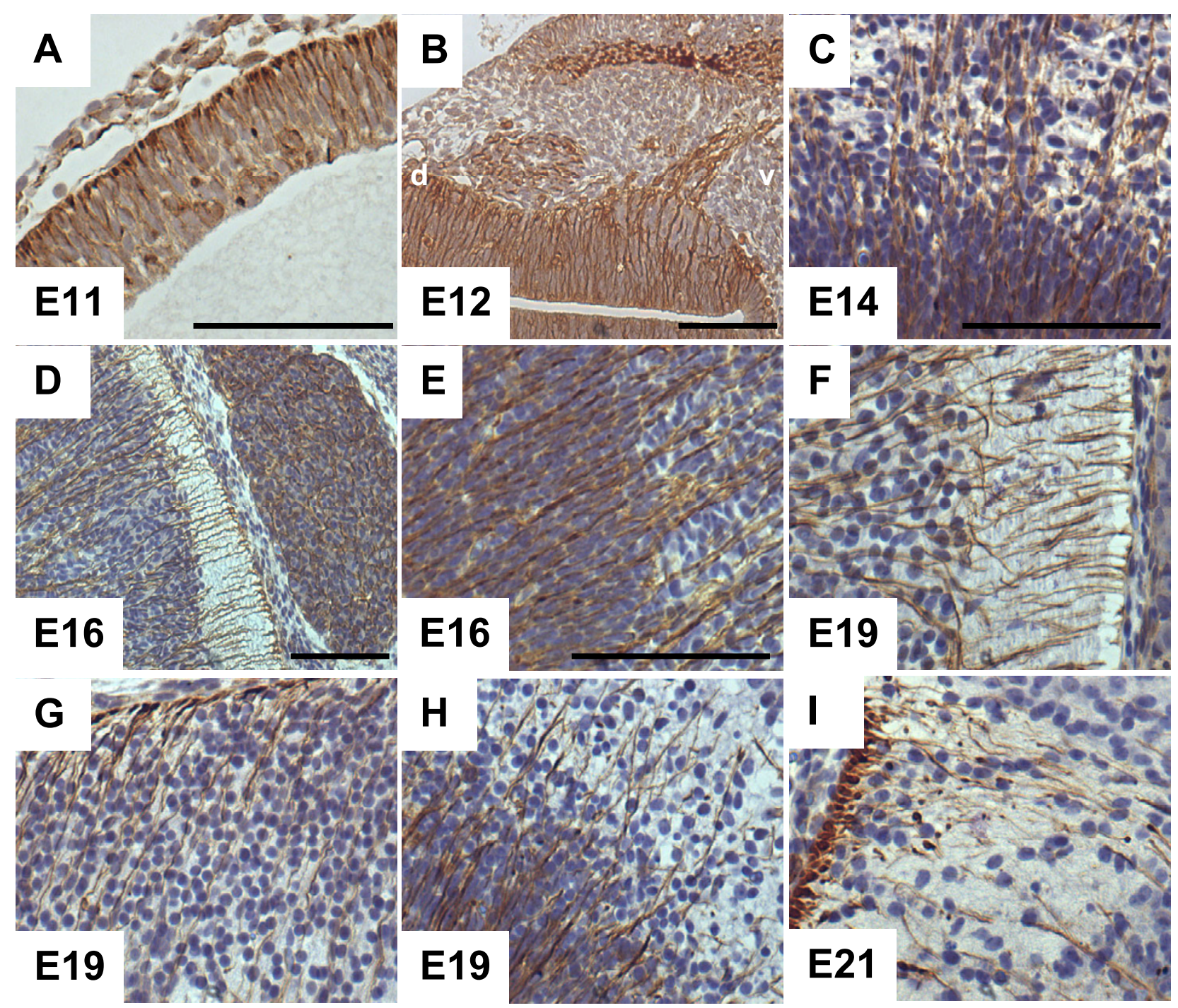

\section{Figure 3}

G-CSF receptor is expressed in the embryonic nervous system. The expression shows characteristics of radial glia cells in terms of long processes and termination in end-feet. A EII forebrain, B EI 2 spinal cord with dorsal root ganglion, axon root and muscle, C EI4 hindbrain, D El6 spinal cord with dorsal root ganglion, E El9 spinal cord, F EI 9 spinal cord, G EI9 hindbrain, H E2 I olfactory bulb, I E2I diencephalon, (Immunohistochemical staining of I0 $\mu \mathrm{m}$ paraffin sections, scale bar = 50 $\mu \mathrm{m}, \mathrm{d}$ : dorsal, E: embryonic day, v: ventral).

incubation with the G-CSF receptor antibody (Santa Cruz Biotechnology, Inc., sc-9173, 1:100) followed overnight at $4{ }^{\circ} \mathrm{C}$ in a humid chamber. Staining was visualized after washing and secondary antibody incubation (anti-rabbit biotin, Dianova) using the avidin-biotin complex (ABC) technique with $\mathrm{DAB}$ as chromogen (DakoCytomation). In order to visualize the nuclei, sections were treated with haemalaun. The specifity of the G-CSF receptor staining is demonstrated by omission of the primary antibody (Additional file 2).

For double immunofluorescence with Nestin, the sections were blocked in 0,2\% BSA/TBS followed by antibody incubation at $4{ }^{\circ} \mathrm{C}$ overnight (anti-mouse nestin, Chemicon International, MAB353, 1:100) and G-CSF receptor antibody. Subsequent washing, sections were incubated for detection with the appropriate fluorescent dye-conju- 

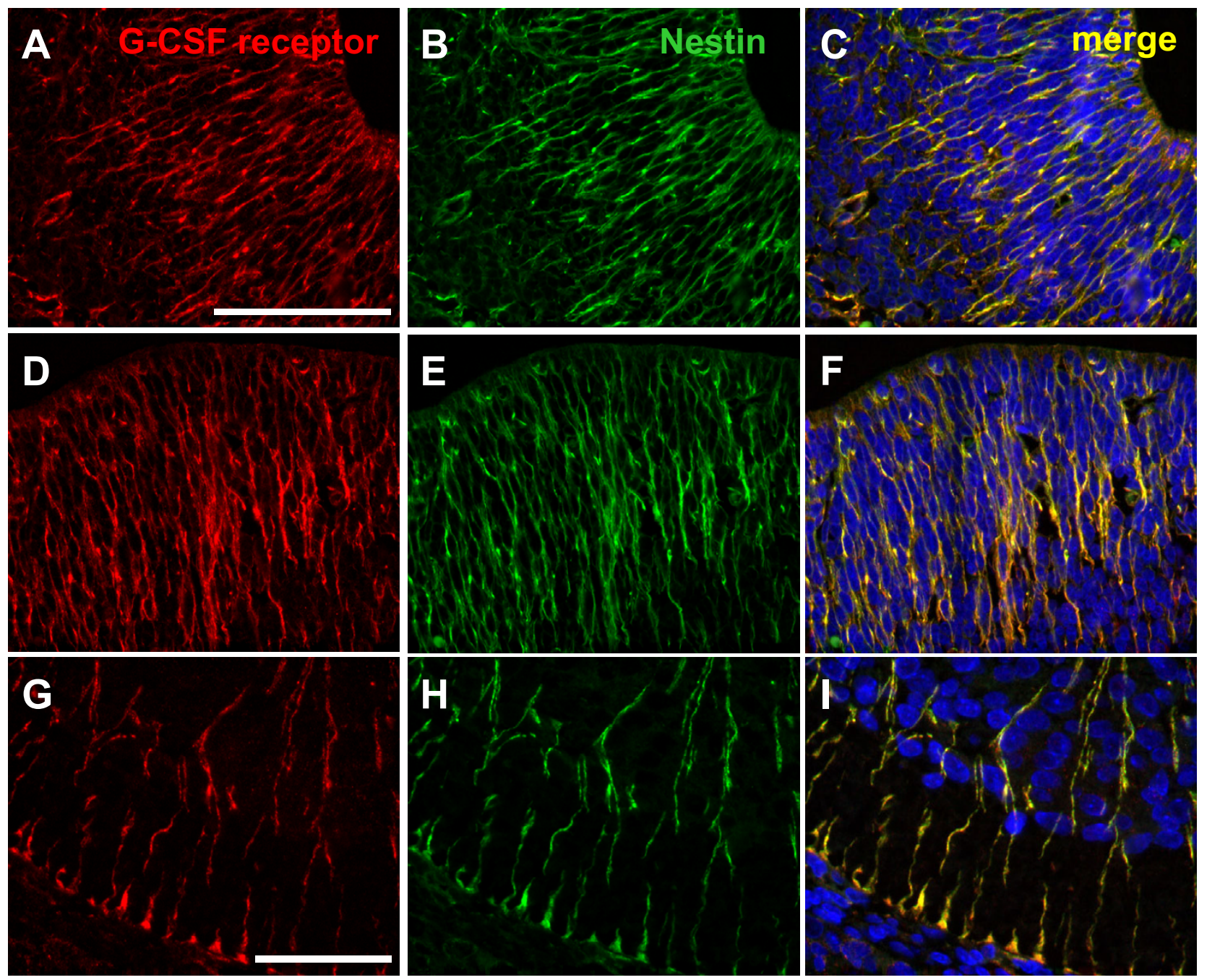

Figure 4

G-CSF receptor and Nestin co-localize in the nervous system of the E 16 rat embryo. The G-CSF receptor staining is shown in red, the signal for Nestin green. On images $\mathbf{A}-\mathbf{C}$ the staining was performed on cortex tissue, $\mathbf{D}-\mathbf{F}$ diencephalon and $\mathbf{G}-\mathbf{I}$ spinal cord tissue. C, F and I are merged images.(Immunofluorescent staining on $10 \mu \mathrm{m}$ paraffin sections, scale bar 50 $\mu \mathrm{m}$, E: embryonic day).

gated secondary antibodies (anti-mouse FITC and antirabbit Cy5, Dianova, 1:200). Nuclear staining was performed using Hoechst33342.

\section{RT-PCR}

RNA of mouse brains (E14, 16, 18, P2) and mouse heads $(\mathrm{E} 11,12)$ respectively was isolated using phenol-chloroform extraction [29] followed by QIAGEN RNeasy Mini Kit purification according to the manufacturer's recommendations. cDNA was synthesized from $5 \mu \mathrm{g}$ total RNA using oligo-dT primers and Superscript III Reverse Tran- scriptase (Invitrogen Corp.). The following primers were used for RT-PCR: mouse G-CSF-790s, GGA GCT CTA AGC TTC TAG ATC; mouse G-CSF-1154as, TAG GGA CTT CGT TCC TGT GAG; mouse G-CSF receptor-2582s, TGT GCC CCA ACC TCC AAA CCA; mouse G-CSF receptor-2817as, GCT AGG GGC CAG AGA CAG AGA CAC. Cycling conditions were as follows for G-CSFR: 5 minutes at $95^{\circ} \mathrm{C}, 30$ seconds at $95^{\circ} \mathrm{C}, 30$ seconds at $60^{\circ} \mathrm{C}, 30$ seconds at $72^{\circ} \mathrm{C}$ for 34 cycles. The final extension time was 7 minutes at $72^{\circ} \mathrm{C}$. For G-CSF, the same program was used after 2 cycles of a touchdown program from $64^{\circ} \mathrm{C}-62^{\circ} \mathrm{C}$. 


\section{Authors' contributions}

AS conceived of the study, FK and CK conducted experiments and analyzed data, AS and FK wrote the manuscript. All authors read and approved the final manuscript.

\section{Additional material}

\section{Additional file 1}

During postnatal development the radial glia scaffold decreases and the G-CSF receptor is expressed in emerging neurons. The figure show a G-CSF receptor immunostaining at postnatal day 7. The decreasing radial glia scaffold is marked by arrows. (10 $\mu \mathrm{m}$ paraffin sections, scale bar $50 \mu \mathrm{m}$ )

Click here for file

[http://www.biomedcentral.com/content/supplementary/1471213X-8-32-S1.pdf]

\section{Additional file 2}

Control for G-CSF receptor immunostaining specificity. The figure demonstrates a control for staining specificity of the G-CSF receptor by omission of the primary antibody. A, E17, spinal cord, G-CSF receptor immunostaining, $\boldsymbol{B}$, control with omission of the primary antibody. (Immunofluorescent staining on $10 \mu \mathrm{m}$ paraffin sections, scale bar 50 $\mu \mathrm{m}$, E: embryonic day).

Click here for file

[http://www.biomedcentral.com/content/supplementary/1471213X-8-32-S2.pdf]

\section{Acknowledgements}

We thank Nadine Bischoff, Ulrike Bolz, Sandra Ellering and Claudia Heuthe for excellent technical assistance.

\section{References}

I. Welte K, Platzer E, Gabrilove JL, Lu L, Levi E, Polivka A, Mertelsmann $\mathrm{R}$, Moore MA: Purification to apparent homogeneity and biochemical characterization of human pluripotent hematopoietic colony-stimulating factor. Haematology and Blood Transfusion 1985, 29:398-40।.

2. Welte K, Platzer E, Lu L, Gabrilove JL, Levi E, Mertelsmann R, Moore MA: Purification and biochemical characterization of human pluripotent hematopoietic colony-stimulating factor. Proc Natl Acad Sci U S A 1985, 82(5): I526- I530.

3. Schneider A, Kruger C, Steigleder T, Weber D, Pitzer C, Laage R, Aronowski J, Maurer MH, Gassler N, Mier W, Hasselblatt M, Kollmar R, Schwab S, Sommer C, Bach A, Kuhn HG, Schabitz WR: The hematopoietic factor G-CSF is a neuronal ligand that counteracts programmed cell death and drives neurogenesis. The Journal of clinical investigation 2005, I I 5(8):2083-2098.

4. Schneider A, Wysocki R, Pitzer C, Kruger C, Laage R, Schwab S, Bach A, Schabitz WR: An extended window of opportunity for $\mathbf{G}$ CSF treatment in cerebral ischemia. BMC biology 2006, 4:36.

5. Sehara $Y$, Hayashi T, Deguchi K, Zhang H, Tsuchiya A, Yamashita T, Lukic V, Nagai M, Kamiya T, Abe K: Potentiation of neurogenesis and angiogenesis by G-CSF after focal cerebral ischemia in rats. Brain research 2007, II 5 I:142-149.

6. Schabitz WR, Schneider A: New targets for established proteins: exploring G-CSF for the treatment of stroke. Trends in pharmacological sciences 2007, 28(4): |57-|6|.

7. Ramón y Cajal S: Études sur la Neurogenèse de Quelques Vertébrés. In Tipografia Artística Madrid, privately printed; 1929:393.

8. Super H, Del Rio JA, Martinez A, Perez-Sust P, Soriano E: Disruption of neuronal migration and radial glia in the developing cere- bral cortex following ablation of Cajal-Retzius cells. Cereb Cortex 2000, I0(6):602-6I3.

9. Bussolino F, Wang JM, Defilippi P, Turrini F, Sanavio F, Edgell C], Aglietta $M$, Arese $P$, Mantovani A: Granulocyte- and granulocytemacrophage-colony stimulating factors induce human endothelial cells to migrate and proliferate. Nature 1989 , 337(6206): 47|-473.

10. Bussolino F, Wang JM, Turrini F, Alessi D, Ghigo D, Costamagna C, Pescarmona G, Mantovani A, Bosia A: Stimulation of the $\mathbf{N a +} / \mathbf{H +}$ exchanger in human endothelial cells activated by granulocyte- and granulocyte-macrophage-colony-stimulating factor. Evidence for a role in proliferation and migration. The Journal of biological chemistry 1989, 264(3 I): I8284- I8287.

II. Bussolino F, Ziche M, Wang JM, Alessi D, Morbidelli L, Cremona O, Bosia $A$, Marchisio PC, Mantovani $A$ : In vitro and in vivo activation of endothelial cells by colony-stimulating factors. The Journal of clinical investigation I99I, 87(3):986-995.

12. Zhao LR, Navalitloha Y, Singhal S, Mehta J, Piao CS, Guo WP, Kessler JA, Groothuis DR: Hematopoietic growth factors pass through the blood-brain barrier in intact rats. Experimental neurology 2007, 204(2):569-573

13. Shyu WC, Lin SZ, Yang HI, Tzeng YS, Pang CY, Yen PS, Li H: Functional recovery of stroke rats induced by granulocyte colonystimulating factor-stimulated stem cells. Circulation 2004, I | 0( I 3): | 847- | 854.

14. Lee ST, Chu K, Jung KH, Ko SY, Kim EH, Sinn DI, Lee YS, Lo EH, Kim $\mathrm{M}$, Roh JK: Granulocyte colony-stimulating factor enhances angiogenesis after focal cerebral ischemia. Brain research 2005 , I058(1-2): | $20-128$.

15. Deindl E, Zaruba MM, Brunner S, Huber B, Mehl U, Assmann G, Hoefer IE, Mueller-Hoecker J, Franz WM: G-CSF administration after myocardial infarction in mice attenuates late ischemic cardiomyopathy by enhanced arteriogenesis. Faseb J 2006 20(7):956-958

16. Schabitz WR, Kollmar R, Schwaninger M, Juettler E, Bardutzky J, Scholzke MN, Sommer C, Schwab S: Neuroprotective effect of granulocyte colony-stimulating factor after focal cerebral ischemia. Stroke; a journal of cerebral circulation 2003, 34(3):745-75 I.

17. Hockfield S, McKay RD: Identification of major cell classes in the developing mammalian nervous system. J Neurosci 1985 5( I 2):3310-3328

18. Parnavelas JG, Nadarajah B: Radial glial cells. are they really glia? Neuron 200I, 3 I (6):88I-884.

19. Rakic P: Guidance of neurons migrating to the fetal monkey neocortex. Brain research 1971, 33(2):47I-476.

20. Rakic P: Mode of cell migration to the superficial layers of fetal monkey neocortex. The Journal of comparative neurology 1972 , 145(I):6I-83.

21. Heyman I, Faissner A, Lumsden A: Cell and matrix specialisations of rhombomere boundaries. Dev Dyn 1995, 204(3):30I-3I 5.

22. Malatesta $P$, Hartfuss $E$, Gotz M: Isolation of radial glial cells by fluorescent-activated cell sorting reveals a neuronal lineage. Development (Cambridge, England) 2000, I 27(24):5253-5263.

23. Noctor SC, Flint AC, Weissman TA, Dammerman RS, Kriegstein AR: Neurons derived from radial glial cells establish radial units in neocortex. Nature 200I, 409(682I):7|4-720.

24. Bonfanti L, Peretto $P$ : Radial glial origin of the adult neural stem cells in the subventricular zone. Prog Neurobiol 2007, 83( I):24-36.

25. Fricker-Gates RA: Radial glia: a changing role in the central nervous system. Neuroreport 2006, I 7(I I): I08I-I084

26. Merkle FT, Tramontin AD, Garcia-Verdugo JM, Alvarez-Buylla A Radial glia give rise to adult neural stem cells in the subventricular zone. Proc Natl Acad Sci U S A 2004, I 0 I (50): I 7528-17532.

27. Gregg C, Weiss S: Generation of functional radial glial cells by embryonic and adult forebrain neural stem cells. I Neurosci 2003, 23(37): II 587-11601.

28. Schneider A, Kuhn HG, Schabitz WR: A role for G-CSF (granulocyte-colony stimulating factor) in the central nervous system. Cell Cycle 2005, 4(I 2): I 753-I 757

29. Chomczynski P, Sacchi N: Single-step method of RNA isolation by acid guanidinium thiocyanate-phenol-chloroform extraction. Analytical biochemistry 1987, I62(I):156-159. 